\title{
Nutritional Profile of Street Runners
}

\section{Carta ao Editor}

Viroj Wiwanitkit

Correspondência: House, Bangkhae, Bangkok Thailand

Mailing address: Wiwanitkit House, Bangkhae, Bangkok Thailand 10160 - Email: wviroj@yahoo.com

\section{Dear Editor,}

I read the recent report on "nutritional profile of street runners" with great interest ${ }^{(1)}$. Goston and Mendes concluded that "although the athletes showed adequate caloric distribution of macronutrients, it was still not sufficient to meet the energy requirements of their modality, suggesting hence that continuous nutritional guidance is needed (1)." Although this work includes a small group of subjects, the results are very interesting. There are some issues for discussion. First, it would be also relevant to know the status of the micronutrients of the subjects, since the authors tried to study their nutritional profile. Second, the finding that there are not sufficient macronutrients should be further studied. The question whether the insufficiency is due to the training or other daily activities, or even poor eating behavior should be investigated. This information can be useful for the designing a good nutritional plan.

\section{REFERENCES}

1. Goston JL, Mendes LL. Nutritional profile of street runners from a sports club in Belo Horizonte City, MG, Brazil. Rev Bras Med Esporte. 2011;17: 13-17

\section{Reply Letter}

\section{Dear Editor,}

Firstly, we thank for the interest shown by the letter's sender on our manuscript, as well as for the opportunity to clarify the highlighted issues.

The intention when studying this group of street runners was to be able to expose some characteristics concerned with the nutritional aspects of a modality (street running) which has increased among the population, regardless of age, race, social and economic group, both in Brazil and worldwide. We were privileged in being able to follow this group of runners, since, despite not being classified as athletes, they keep systematic and strict training routines, with follow-up from many health professionals and who punctually participate in running events annually scheduled both in Brazil and abroad. Therefore, we are aware of the study's limitation regarding the sample size and the results should be carefully interpreted since they are not representative of all practitioners of the modality under consideration. Nevertheless, as this is a modality which has been practiced by so many individuals, we found the results relevant in the current context and that they could contribute to enrich the understanding of professionals and researchers who either work with or appreciate topics concerned with sports nutrition as well as this sports modality.

Regarding the questioning on the conclusion about the macronutrients, it is worth mentioning that the results presented and discussed considered the runners' population studied as well as the evaluation of its food intake calculated based on the DRIs. Thus, it was not mentioned that the energetic ingestion was simply below the recommendations, rather, that when it was compared to the values suggested by the DRIs ${ }^{(1)}$, Guideline of the Brazilian Society of Sports Medicine ${ }^{(2)}$ and other authors ${ }^{(3,4)}$, the energetic ingestion was kept below the optimum levels, which could reflect on the general performance as a whole. Therefore, it is interesting to stress that the presented results should be better investigated, especially concerning the evaluation of macronutrients involving recreational street runners.
As far as the evaluation of micronutrients is concerned, we agree that evaluating the nutritional status certainly includes not only the analysis of macronutrients but also micronutrients. However, one should consider that the evaluation of micronutrients would be more time-consuming besides the methodology being more demanding on the control of its ingestion. Additionally, how could the micronutrients ingestion be evaluated without their concomitant biochemical evaluation? Since our aim in this investigation was not to evaluate the ingestion of micronutrients, we chose not to work with this issue and we understand this constitutes a limitation to this study. Moreover, another consideration is the lack of clear data on the micronutrients' need of athletes and practitioners. Would the micronutrients' need be increased in athletes? On the other hand, had the micronutrients needs not been met by the athletes, would they be able to reach an Olympic level? According to recent positioning of scientific entities ${ }^{(2)}$ aimed at athletic nutrition and performance, the ingestion of a varied and balanced diet seems to fulfill the increase in the micronutrients' need caused by training.

Finally, we believe that generally speaking, the publishing of our results and of the discussion in all the aspects contemplated in the present study corroborates the need of nutritional reeducation in different groups of athletes, especially in recreational street runners. This study somehow reflected our practical perception that satisfactory meeting of nutritional demands of athletes requires the designing of careful food planning which includes dietetic manipulation adapted to their sports modality and life style. Furthermore, there are countless factors -and not only the lack of information on nutrition - which can expressively influence on the typical eating pattern of a group of athletes and consequently, on its performance and health.

Once again, we thank for the considerations and make ourselves available for future clarification.

With best regards,

\section{REFERENCES}

1. Food and Nutrition Board, Institute of Medicine, National Academies. Dietary Reference Intakes (DRI) for energy, carbohydrate, fiber, fat, fatty acids, cholesterol, protein, and amino acids (macronutrients. Washington: National Academy press, 2002/2005. Disponível em:<http://www,nap,edu/ openbook,php?record_id=10490\&page=1325>. Acesso em: 05 jun. 2009.

2. Diretriz da Sociedade Brasileira de Medicina do Esporte (DSBME). Modificações dietéticas, reposição hídrica, suplementos alimentares e drogas: comprovação de ação ergogênica e potenciais riscos para

saúde. Rev Bras Med Esporte 2009;15(Supl 3):3-12.

3. Schroder S, Fischer A, Vock C, Bohme M, Schmelzer C, Dopner M, et al. Nutrition concepts for elite distance runners based on macronutrient and energy expenditure. J Athl Train 2008;43:489-504.

4. Motonaga $\mathrm{K}$, Yoshida S, Yamagami F, Kawano T, Takeda E. Estimation of total daily energy expenditure and its components by monitoring the heart rate of Japanese endurance athletes. J Nutr Sci Vitaminol (Tokyo) 2006;52:360-7. 